\title{
Plant nematodes in South Africa. 11. Checklist of plant nematodes of the protected areas of KwaZulu-Natal
}

\begin{tabular}{|c|c|}
\hline \multicolumn{2}{|c|}{$\begin{array}{l}\text { Authors: } \\
\text { Mariette Marais }{ }^{1} \\
\text { Antoinette Swart }^{1}\end{array}$} \\
\hline \multicolumn{2}{|c|}{$\begin{array}{l}\text { Affiliations: } \\
{ }^{1} \text { National Collection of } \\
\text { Nematodes (Biosystematics } \\
\text { Programme), ARC-Plant } \\
\text { Protection Research Institute, } \\
\text { South Africa }\end{array}$} \\
\hline \multicolumn{2}{|c|}{$\begin{array}{l}\text { Correspondence to: } \\
\text { Mariette Marais }\end{array}$} \\
\hline \multicolumn{2}{|c|}{$\begin{array}{l}\text { Email: } \\
\text { maraism@arc.agric.za }\end{array}$} \\
\hline \multicolumn{2}{|c|}{$\begin{array}{l}\text { Postal address: } \\
\text { Private Bag X134, } \\
\text { Queenswood 0121, } \\
\text { South Africa }\end{array}$} \\
\hline \multicolumn{2}{|c|}{$\begin{array}{l}\text { Dates: } \\
\text { Received: } 02 \text { May } 2012 \\
\text { Accepted: } 03 \text { Oct. } 2012 \\
\text { Published: } 08 \text { Mar. } 2013\end{array}$} \\
\hline \multicolumn{2}{|c|}{$\begin{array}{l}\text { How to cite this article: } \\
\text { Marais, M. \& Swart, A., } \\
\text { 2013, 'Plant nematodes in } \\
\text { South Africa. 11. Checklist } \\
\text { of plant nematodes of the } \\
\text { protected areas of KwaZulu- } \\
\text { Natal', Koedoe } 55(1) \text {, Art. } \\
\text { \#1086, } 2 \text { pages. http:// } \\
\text { dx.doi.org/10.4102/koedoe. } \\
\text { v55i1.1086 }\end{array}$} \\
\hline \multicolumn{2}{|c|}{$\begin{array}{l}\text { Note: } \\
\text { Additional supporting } \\
\text { information may be found } \\
\text { in the online version of } \\
\text { this article as an Online } \\
\text { Appendix: http://dx.doi. } \\
\text { org/10.4102/koedoe. } \\
\text { v55i1.1086-1. }\end{array}$} \\
\hline \multicolumn{2}{|c|}{$\begin{array}{l}\text { Copyright: } \\
\text { (C) 2013. The Authors. } \\
\text { Licensee: AOSIS } \\
\text { OpenJournals. This work } \\
\text { is licensed under the } \\
\text { Creative Commons } \\
\text { Attribution License. }\end{array}$} \\
\hline Read online: & \\
\hline 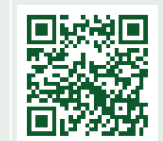 & $\begin{array}{l}\text { Scan this QR } \\
\text { code with your } \\
\text { smart phone or } \\
\text { mobile device } \\
\text { to read online. }\end{array}$ \\
\hline
\end{tabular}

Nematodes are some of the most abundant soil organisms and are an essential part of soil ecology. These organisms are used as indicator organisms and can be linked to soil health. Biological collections contain vast amounts of data, with the National Collection of Nematodes housed at the Plant Protection Research Institute, Agricultural Research Council being no different. During the digitising of the collection a number of unpublished records of plant nematodes reported from protected areas in KwaZulu-Natal were found in the South African Plant-Parasitic Nematode Survey database. A total of 222 plant nematode species belonging to 39 genera were reported from the province, with only 94 of these species reported from the protected areas and 172 and 159 species reported from uncultivated (outside the protected areas) and cultivated areas, respectively. Only nine species, Criconema silvum, Criconema talanum, Helicotylenchus marethae, Ogma dracomontanum, Ogma louisi, Ogma ueckermanni, Paralongidorus deborae, Trichodorus rinae and Xiphinemella marindae were described from protected areas, whilst $O$. dracomontanum, $P$. deborae and $T$. rinae were subsequently also reported from other provinces.

Conservation implications: A higher degree of diversity of nematodes was observed in the unprotected areas of the province. The observation suggests that nematode fauna, and by implication also other invertebrates, are not adequately protected.

\section{Introduction}

Since the late 1950s nematodes were collected, identified and deposited in the National Collection of Nematodes at the Plant Protection Research Institute, Agricultural Research Council, Pretoria. Descriptions and locality data of new species were published, but the incidence of plant nematodes in the protected areas of KwaZulu-Natal was never consolidated in a single document as was done for a number of protected areas in other provinces (Botha \& Heyns 1990; Van den Berg, Marais \& Tiedt 2007; Van der Vegte \& Heyns 1963). In 1987 the National Collection of Nematodes initiated the South African Plant-Parasitic Nematode Survey (SAPPNS) to record the biodiversity of plant nematodes in South Africa (Marais 2006). As part of this initiative, surveys were undertaken in various protected areas, including those in KwaZulu-Natal (Van den Berg 1992). During digitising the specimens of the National Collection of Nematodes, a number of unpublished records of plant nematodes reported from protected areas in KwaZulu-Natal were discovered.

\section{Results and discussion}

The checklist reflects collections between 1963 and 2006 from 18 protected areas in KwaZuluNatal. The SAPPNS database contains 450 records of nematodes sampled in uncultivated areas in KwaZulu-Natal, of which 161 are from localities in protected areas (Online Appendix). The database also contains 580 records of localities sampled in cultivated areas, which include crop fields, plantations, gardens and sports fields. It was found that 94 plant nematode species were reported from protected areas (Table 1), 172 species from uncultivated areas (outside the protected areas) and 159 species from cultivated areas. In total, 222 different plant nematode species are currently reported for KwaZulu-Natal. Of these, 54 species were described for the province but only nine species were described for the protected areas in the province.

The classification of South African plant-parasitic nematodes followed here is a synthesis of the classification by Maggenti et al. (1988) for Tylenchina and Decraemer (1995) and Duarte et al. (2010) for Trichodoridae. The synonymisation of the genera Longidoroides and Siddiqia with Paralongidorus, as proposed by Escuer and Arias (1997), is accepted. Authorities for genera regarded as valid here are Marais (2001) for Helicotylenchus, Escuer and Arias (1997) for Paralongidorus, Brzeski (1998) for Paratylenchus, Handoo (2000) for Tylenchorhynchus and Hunt, Luc and Manzanilla-López (2005) for Criconemoides. 
TABLE 1: Number of plant nematode species recorded from KwaZulu-Natal.

\begin{tabular}{|c|c|c|c|c|c|c|c|}
\hline Family & Genera & KZN & Protected areas & $\begin{array}{l}\text { Uncultivated areas } \\
\text { (excluding the } \\
\text { protected areas) }\end{array}$ & $\begin{array}{l}\text { Cultivated areas } \\
\text { (crops, plantations, } \\
\text { sport fields) }\end{array}$ & $\begin{array}{c}\text { Described from } \\
\text { KZN }\end{array}$ & $\begin{array}{l}\text { Reported from only } \\
\text { KZN }\end{array}$ \\
\hline Anguinidae & 2 & 2 & 0 & 0 & 2 & 0 & 0 \\
\hline Dolichodoridae & 3 & 3 & 0 & 0 & 0 & 0 & 2 \\
\hline Belonolaimidae & 6 & 16 & 2 & 9 & 12 & 4 & 2 \\
\hline Pratylenchidae & 4 & 17 & 6 & 9 & 14 & 1 & 2 \\
\hline Hoplolaimidae & 5 & 40 & 22 & 34 & 28 & 1 & 0 \\
\hline Criconematidae & 6 & 47 & 29 & 42 & 33 & 11 & 6 \\
\hline Tylenchulidae & 4 & 10 & 2 & 4 & 8 & 3 & 2 \\
\hline Trichodoridae & 3 & 10 & 4 & 9 & 6 & 3 & 3 \\
\hline Longidoridae & 3 & 68 & 27 & 58 & 50 & 28 & 7 \\
\hline Tylencholaimidae & 1 & 1 & 1 & 1 & 0 & 1 & 1 \\
\hline $\begin{array}{l}\text { Total number of plant } \\
\text { nematode species }\end{array}$ & - & 222 & 94 & 172 & 159 & 54 & 27 \\
\hline
\end{tabular}

KZN, KwaZulu-Natat.

\section{Acknowledgements}

We thank various colleagues for collecting the samples, the taxonomists at the ARC-PPRI and (the former) Rand Afrikaans University for species identification and the South African Biodiversity Information Facility for financial assistance to digitise a portion of the National Collection of Nematodes.

\section{Competing interests}

The authors declare that they have no financial or personal relationship(s) that may have inappropriately influenced them in writing this article.

\section{Authors' contributions}

M.M. (ARC-Plant Protection Research Institute) is the coordinator of the SAPPNS, project leader of digitising the National Collection of Nematodes and taxonomist responsible for Helicotylenchus and Belonolaimidae, Dolichoridae, Trichodoridae and the subfamily Meloidogyninae. M.M. was responsible for writing the draft concept of the manuscript. A.S. (ARC-Plant Protection Research Institute) is the taxonomist responsible for the Longidoridae, Anguinidae, Aphelenchoididae and the subfamily Heteroderinae at the Collection and was responsible for the final review of the manuscript. M.M. and A.S. both contributed to writing the article.

\section{References}

Botha, A. \& Heyns, J., 1990, 'A preliminary check list of the free-living and plantparasitic nematodes of the Kruger National Park', Koedoe 33(2), 73-76. http:// dx.doi.org/10.4102/koedoe.v33i2.442

Brzeski, M., 1998, Nematodes of Tylenchina in Poland and temperate Europe, Museum i Instytut Zoologii Polska Akademia Nauk, Warzawa.

Decraemer, W., 1995, The family Trichodoridae: Stubby root and virus vector nematodes, Kluwer Academic Press, Dordrecht. http://dx.doi.org/10.1007/97894-015-8482-1

Duarte, I.M., De Almeida, M.T., Brown, D.J.F., Marques, I. Nielsen, R. \& Decraemer, W., 2010, 'Phylogenetic relationships, based on SSU rDNA sequences, among the didelphic genera of the family Trichodoridae from Portugal', Nematology 12(2), 171-180. http://dx.doi.org/10.1163/156854109X461721

Escuer, M. \& Arias, M., 1997, 'Paralongidorus iberis sp.n. and P. monegrensis sp.n. from Spain with a polytomous key to the species of the genus Paralongidorus Siddiqi, Hooper \& Khan, 1963 (Nematoda: Longidoridae)', Fundamental and Applied Nematology 20(2), 135-148.

Handoo, Z., 2000, 'A key and diagnostic compendium to the species of the genus Tylenchorhynchus Cobb, 1913 (Nematoda: Belonolaimidae)', Journal of Nematology 32(1), 20-34. PMid:19270946

Hunt, D.J., Luc, M. \& Manzanilla-López, R.H., 2005, 'Identification, morphology and biology of plant parasitic nematodes', in M. Luc, R.A. Sikora \& J. Bridge (eds.), Plant parasitic nematodes in subtropical and tropical agriculture, 2nd edn., pp. 11-52,
CABI Publishing, Wallingford. http://dx.doi.org/10.1079/9780851997278.0011

Maggenti, A.R., Luc, M., Raski, D.J., Fortuner, R. \& Geraert, E., 1988, 'A reappraisal of Tylenchina (Nemata). 11. List of generic and supra-generic taxa, with their junior synonyms', Revue de Nématologie 11(2), 177-188.

Marais, M., 2001, 'A monograph of the genus Helicotylenchus Steiner, 1945 (Nemata: Hoplolaimidae)', PhD dissertation, Department of Entomology and Nematology, University of Stellenbosch.

Marais, M., 2006, 'South African Plant-Parasitic Nematode Survey (SAPPNS)', Plant Protection News 67, 6.

Van den Berg, E., 1992, 'Description of two new Ogma Southern, 1914 species (Nemata: Criconematoidea) with a list of plant-parasitic nematode species from Natal', Koedoe 35(1), 9-18. http://dx.doi.org/10.4102/koedoe.v35i1.385

Van den Berg, E., Marais, M. \& Tiedt, L.R., 2007, 'Plant nematodes in South Africa. 10. Check-list of plant nematodes from the Goegap and Witsand Nature Reserves, Northern Cape Province, with a description of a new Rotylenchus species (Hoplolaimidae: Nematoda)', African Plant Protection 13, 28-35, viewed 22 September 2011, from http://journals.sabinet.co.za/WebZ/AdvancedQuery?ses sionid=01-64234-250806035

Van der Vegte, F.A. \& Heyns, J., 1963, 'A report on nematodes found in soil and root samples from the Kruger National Park', Koedoe 6(1), 134-136. http://dx.doi. org/10.4102/koedoe.v6i1.820 